\title{
PRINCIPLES OF CROP MODELLING AND SIMULATION: III. MODELING OF ROOT GROWTH AND OTHER BELOWGROUND PROCESSES, LIMITATIONS OF THE MODELS, AND THE FUTURE OF MODELING IN AGRICULTURE
}

\author{
D. DOURADO-NETO ${ }^{1,6}$; D. A. TERUEL ${ }^{1,7}$; K. REICHARDT ${ }^{2,5,6}$; D.R. NIELSEN ${ }^{3}$; J. A. FRIZZONE ${ }^{1,6}$; \\ O.O.S. BACCHI ${ }^{5,6}$
}

${ }^{1}$ Depto. de Agricultura-ESALQ/USP, C.P. 9, CEP: 13418-900 - Piracicaba, SP, Brasil. ${ }^{2}$ Depto. de Física e Meteorologia-ESALQ/USP, C.P. 9, CEP: 13418-900 - Piracicaba, SP, Brasil. ${ }^{3}$ Dept. of Land, Air and Water Resources, University of California, Davis, USA.

${ }^{4}$ Depto. de Engenharia Rural-ESALQ/USP, C.P. 9, CEP: 13418-900 - Piracicaba, SP, Brasil.

${ }^{5}$ Centro de Energia Nuclear na Agricultura/USP, C.P. 96, CEP: 13400-970 - Piracicaba, SP, Brasil.

${ }^{6}$ Bolsista do CNPq

${ }^{7}$ Bolsista da FAPESP

\begin{abstract}
The first models of temporal variation of root systems appeared over 20 years ago. The complex architectural geometry of root systems; the wide range in size and diameter and the rapid growth and decomposition of finest roots; the different physiological activity of roots of different ages; the complex microbial processes occurring at the root-soil interface; the symbiotic relationships in the rhizosphere; the variable soil environment (physical, chemical and biological) in which roots develop are the challenges of quantifying the root growth. The models are not simple mechanisms to archive information in order to produce forecasts. Modeling represents a better way of synthesizing knowledge about different components of a system, summarizing data, and transferring research results to users. Key Words: crop modeling, simulation
\end{abstract}

\section{PRINCÍPIOS DE MODELAGEM E SIMULAÇ̃̃: III. MODELAGEM DO SISTEMA RADICULAR E OUTROS PROCESSOS SUBTERRÂNEOS, LIMITAÇÕES DOS MODELOS E O FUTURO DA MODELAGEM EM AGRICULTURA}

RESUMO: Os primeiros modelos que contemplaram a variação espacial e temporal de sistemas radiculares foram apresentados há mais de 20 anos. A complexa arquitetura dos sistemas radiculares; a ampla faixa de variação no tamanho e no diâmetro, bem como no rápido crescimento e decomposição de raízes finas; as diferentes atividades fisiológicas das raízes de diferentes idades; os complexos processos microbiológicos que ocorrem na interface raiz-solo; as relações simbióticas na rizosfera; as variações químicas, físicas e biológicas que ocorrem no solo (local onde as raízes se desenvolvem) são os desafios da quantificação do crescimento radicular. Os modelos não são simples mecanismos para arquivar informações, produzindo estimativas. Os modelos representam o melhor mecanismo de sintetizar conhecimento sobre diferentes componentes do sistema, arquivando dados de forma sintética, e transferindo resultados de pesquisa para os usuários.

Descritores: modelagem em agricultura, simulação

\section{THE CHALLENGE OF MODELING ROOT GROWTH AND OTHER BELOW GROUND PROCESSES}

During the plant vegetative growth, its root system expands vertically and laterally, occupying a volume of soil that may be larger than the dimensions of the plant shoot system.

Fine roots can represent more than $50 \%$ of the total mass of roots, and these present a high turnover rate: growing, being active for a few days, dying, decomposing, and being replaced by new fine roots. 
The root system development is usually interrupted after the flowering stage, senescing quickly during the maturation stage in annual plants.

The challenges of quantifying the growth, turnover, and senescence of root systems derive, among other things, from (Luxmoore \& Stolzy, 1987): (i) the complex architectural geometry of root systems; (ii) the wide range in size and diameter from the finest roots to the thickened roots of perennial plants; (iii) the different physiological activities of roots of different ages; (iv) the rapid growth and decomposition of fine roots; (v) the complex microbial processes occurring at the root-soil interface; (vi) symbiotic relationships in the rhizosphere; (vii) the variable soil environment (physical, chemical and biological) in which roots develop.

This complexity makes us think that the mechanistic modeling of root growth and other processes in the rhizosphere is a problem virtually impossible to solve, however, this fact only reinforces our need for pragmatism during all stages of development of the model.

\section{SIMULATION OF GROWTH AND STRUCTURE OF ROOT SYSTEMS}

A root system can be regarded as the result of the accumulated effects of growth and branching of individual root tips and the root tissue behind these tips in response to local soil conditions and the overall state of the plant (Diggle, 1988).

The first models of temporal variation of root systems appeared over 20 years ago, such as the models described in Hackett \& Rose (1972) and Lungley (1973). Later on, models such as those developed by Rose (1983) and by Porter et al. (1986) became available, making possible the simulation of number and length of different root system components (branches of different orders), but without maintaining a record of the location of each component of the system.

Recent efforts have been made towards the development of models that generate a threedimensional representation of the root system, with the allocation of all branches and portions of the root to each interval of time (Diggle, 1988; Pages et al., 1989). More recently, Clausnitzer \& Hopmans (1993) present a model that not only simulates the root growth as a process controlled by the physical conditions of the soil, but that also simultaneously simulates the effect of the root growth on the soil conditions.
During the development and application of those models, some parameters should be known: (i). parameters of time: the total duration of the simulation and the duration of each interval; (ii). temperature parameters, because the growth rates are dependent on the temperature (Diggle, 1988): therefore the variation of the temperature of the soil should be known in depth; (iii). growth and branching parameters, as root elongation rate, branching density, duration of apical non-branching, branching probability, and others (Hackett \& Rose, 1972; Lungley, 1973; Porter et al., 1986; Rose, 1983; Diggle, 1988); (iv). parameters affecting the growth direction, as geotropism index, deflection angle, and maximum branching angle (Diggle, 1988; Pages et al., 1989).

\section{SIMULATION OF THE MICROBIAL POPULATION DYNAMICS IN THE RHIZOSPHERE}

Rhizosphere is defined as the zone of soil close to the roots with a large population of microorganisms, much higher than the one in the bulk soil (Clark, 1949).

Newman \& Watson (1977) were the pioneers in developing a computerized model to forecast the effects of soil water content, root density, root exudation rate, and the initial microbial concentration on population dynamics and microbes distribution in the rhizosphere.

The microbial populations in the rhizosphere can have significant effects on root growth and branching, and also manifest competition for nutrients, reducing the nutrient uptake by the plant. The incorporation of those effects in root growth and uptake models has not yet been done, although it might increase the accuracy of such models. However, the empirical data used in the development and validation of several models have come from measurements of non-sterile substrate, and therefore, the effects of the microorganisms have been computed in some way, even if indirectly (Luxmoore \& Stolzy, 1987).

\section{RELIABILITY AND ACCURACY: LIMITATIONS OF THE MODELS}

The professionals working with modeling of biological processes and the users of such models are always confronted with the following question: how 
to ensure the reliability and accuracy of the model they are building or using? A critical review in the selection of the databases used for the model development or in its posterior application can help to minimize the problem.

Information has been gathered on environmental, biological, and management variables. And although one is likely to find good data collections on soil and climate factors, the available information on physiologic processes and crop phenology is insufficient, demanding much more experimentation (Hesketh \& Dale, 1987).

The modelers should always have in mind how their models should work adequately for a certain purpose, that is, they should know the main intermediate processes, which take place at a given scale in the system to be modeled, and also know the expected set of output information. Hence, they should search for historical collections of data that could help them develop and validate the model, along with new experimental data to be measured in order to develop a mechanism of calculations that produces a simulation as close as possible to reality.

A model is as precise and reliable as the database used in its development, and a simulation is as accurate and reliable as the database used to feed the model.

Another point is that the model must accommodate the variability of the data that feed it, otherwise noises will disturb the resulting output, independent of data quality (Wisiol, 1987). That happens, for instance when the models are not prepared for processes in which response is delayed in relation to the input signal, and when feedback occurs.

A model must have the same sensitivity of the system that it represents, that is, it must have the ability to capture differences in the input parameters and produce different results, in the same way it would happen in the real system.

On the other hand, a hyper sensitive model must be avoided, when the model does not take into account the adaptability of the crop, producing different results from slightly different events, while the real system maintains a constant response. For example, a plant, in variable degrees according to the species and cultivar, can tolerate a certain degree of water deficiency for a certain period of time, in a certain stage of its development, without any decrease in yield.

\section{THE FUTURE OF MODELING INAGRICULTURE}

Models are useful tools for agricultural purposes. Several examples could be mentioned, in the areas of irrigation management, soil physics, plant nutrition, plant diseases, and related topics. There is even a model used in biology and agriculture for a long time, the one invented by Gregor Mendel in 1865 to describe the progeny resulting from crossings plants with one or more characters controlled by dominantrecessive genes.

One of the most important uses of models is to forecast the results produced by a given system in response to a given set of inputs. One very important future use of models in agriculture is to forecast the effects of certain environmental conditions and agricultural practices on crop performance.

Being useful tools for researchers, models have also been developed and applied to solve complex agricultural problems.

Plant modeling has progressed clearly in the past 30 years, mainly due to the growing demand for models.

There was practically no demand for farmlevel models a couple of decades ago, but nowadays, many farms are equipped with microcomputers and data-loggers, with access to mainframe computers through the Internet. The users are growing quickly in number and degree of sophistication (Grable, 1987).

Another growing group of model users is the governmental agencies, concerned with developing agricultural and environmental policies.

Another potential use of models comes from their ability in helping to set research priorities and guide fund allocations (Ruttan, 1983). Modeling can provide quantitative descriptions and the understanding of agricultural systems, helping to pinpoint areas where knowledge is lacking and helping in the design of more adequate and effective experiments (France \& Thornley, 1984).

\section{FINAL CONSIDERATIONS}

Models are not simple mechanisms to archive and synthesize information for producing forecasts. Modeling represents a better way of synthesizing knowledge about different components of a system, summarizing data, and transferring research results to users (France \& Thornley, 1984). 


\section{REFERENCES}

CLARK, F.E. Soil microorganisms and plant roots. Advances in Agronomy, v.1, p.241-288, 1949.

CLAUSTNITZER, V.; HOPMANS, J. W. An algorithm for three dimensional, simultaneous modeling of root growth and transient soil water flow: (version 1.0). Davis: LAWR/ UCDAVIS, 1993. 108p.

DIGGLE, A.J. ROOTMAP: a model in threedimensional coordinates of the growth and structure of fibrous root systems. Plant and Soil, v.105, p.169-178, 1988.

FRANCE, J.; THORNLEY, J.H.M. Mathematical models in agriculture. London: Butterworths, 1984.

GRABLE, A.R. The future of applied plant growth modeling. In: WISIOL, K.; HESKETH, J.D. Plant growth modeling for resource management: current models and methods. Boca Raton: CRC Press, 1987. p.141-156.

HACKETT, C.; ROSE, D. A. A model of the extension and branching of a seminal root of barley, and its use in studying relations between root dimensions: 1. the model. Australian Journal of Biological Sciences, v.25, p. 669-679, 1972.

HESKETH, J.D.; DALE, R.F. Data for plant growth modeling: an evaluation. In: WISIOL, K.; HESKETH, J.D. Plant growth modeling for resource management: current models and methods. Boca Raton: CRC Press, 1987. v.1, p. 57-71.

LUNGLEY, D. R. The growth of root systems: a numerical computer simulation model. Plant and Soil, v.38, p.145-159, 1973.
LUXMOORE, R.J.; STOLZY, L.H. Modeling belowground processes of roots, the rhizosphere, and soil communities. In: WISIOL, K.; HESKETH, J.D. Plant growth modeling for resource management: quantifying plant processes. Boca Raton: CRC Press, 1987. v.2, p.129-153.

NEWMAN, E.I.; WATSON, A. Microbial abundance in the rhizosphere: a computer model. Plant and Soil, v.48, p.17, 1977.

PAGES, L.; JORDAN, M. O.; PICARD, D. A simulation model of the three-dimensional architecture of the maize root system. Plant and Soil, v.119, p.147-154, 1989.

PORTER, J. R.; KLEPPER, B.; BELFORD, R. K.; A model (WHTROOT) which synchronizes root growth and development with shoot development for winter wheat. Plant and Soil, v.92, p.133-145, 1986.

ROSE, D. A. The description of the growth of root systems. Plant and Soil, v.75, p.405-415, 1983.

RUTTAN, V.W. Agricultural research policy issues. Horticultural Science, v.18, p.809, 1983.

WISIOL, K. Choosing a basis for yield forecasts and estimates. In: WISIOL, K.; HESKETH, J.D. Plant growth modeling for resource management: current models and methods. Boca Raton: CRC Press, 1987 . v.1, p.75-103.

Recebido para publicação em 10/07/98 Aceito para publicação em 03/08/98 